\title{
ANALISIS ABNORMAL RETURN DAN LIKUIDITAS SAHAM SEBELUM DAN SESUDAH STOCK SPLIT PERIODE 2008-2012
}

\author{
Wening Asriningsih \\ Universitas Negeri Yogyakarta, Indonesia \\ Email: wening.asri@yahoo.com
}

\begin{abstract}
Abstrak: Analisis Abnormal Return dan Likuiditas Saham Sebelum dan Sesudah Stock Split Periode 2008-2012. Penelitian ini bertujuan untuk mengetahui perbedaan abnormal return dan likuiditas saham sebelum dan sesudah stock split di perusahaan yang terdaftar di Bursa Efek Indonesia periode 2008-2012. Penelitian ini menggunakan desain event study, dimana dilakukan pengamatan 10 hari sebelum dan 10 hari sesudah peristiwa. Analisis data yang digunakan dalam penelitian ini adalah Uji Paired Sampel t-test dan Uji Wilcoxon Signed Rank test. Hasil penelitian menunjukkan bahwa tidak terdapat perbedaan abnormal return namun terdapat perbedaan likuiditas yang signifikan sebelum dan sesudah stock split periode 2008-2012. Hasil penelitian ini juga menunjukkan bahwa stock split mampu meningkatkan likuiditas.

Kata kunci: stock split, abnormal return, likuiditas.

Abstract: The Analysis of Abnormal Return and Liquidity Before and After Stock Split in 2008-2012. This study is aimed to find out the differences abnormal return and liquidity before and after stock split at the companies listed for the period of 2008 2012. This study is using event study, in which the writer observed within 10 days before and 10 days after the event date. Data analysis that is uses in this research is Paired Sample t-test and Wilcoxon Signed Rank test. The result of the study show that: there was no differences in abnormal return but there was a significant difference in liquidity before and after stock split. The result of this study indicate the stock split may improve liquidity.
\end{abstract}

Key words: stock split, abnormal return, liquidity

\section{PENDAHULUAN}

Perkembangan pasar modal yang semakin meluas menjadikan pasar modal sebagai alternatif investasi bagi masyarakat. Dalam menentukan perusahaan yang akan dijadikan sebagai tempat investasi, diperlukan berbagai pertimbangan karena tidak sembarang perusahaan bisa dipilih sebagai tempat investasi.

Para investor yang memilih untuk berinvestasi di pasar modal, harus membuat keputusan yang dianggap bisa memberikan return sesuai dengan harapan mereka.
Dalam hal ini, informasi merupakan hal yang sangat penting bagi investor. Karena informasi merupakan kebutuhan mendasar bagi para investor dalam melakukan pengambilan keputusan yang berkaitan dengan pemilihan portofolio dengan tingkat risiko tertentu.

Salah satu informasi yang tersedia dalam pasar modal adalah pengumuman stock split atau pemecahan saham. Menurut Jogiyanto (2010: 561) "Pemecahan saham adalah memecah selembar saham menjadi n lembar saham". Dengan kata lain stock split adalah 
tindakan pemecahan nominal saham menjadi nominal yang lebih kecil, misalnya dari nominal Rp10.000 per saham menjadi nominal Rp5.000 per saham. Menurut Mohamad Samsul (2006: 87) "Tindakan memperkecil nilai nominal saham akan membuat jumlah saham menjadi semakin bertambah banyak". Tindakan stock split bertujuan untuk menempatkan harga pasar saham dalam optimal trading range.

Stock split tidak mempengaruhi aliran kas perusahaan, sehingga stock split tidak akan merubah kekayaan perusahaan. Hal itu berarti stock split tidak memiliki nilai ekonomis. Meskipun secara teoritis stock split tidak memiliki nilai ekonomis, akan tetapi peristiwa stock split banyak terjadi di pasar modal. Di pasar modal Indonesia, terdapat sekitar 102 peristiwa stock split pada tahun 2000-2012 (Indonesian Capital Market Directory, 2001- 2012).

Banyaknya peristiwa stock split di pasar modal mengindikasikan bahwa stock split merupakan alat yang cukup penting dalam praktik pasar modal. Hal ini menjadikan stock split sebagai suatu fenomena yang diperdebatkan dan menjadi teka-teki bagi para ahli keuangan. Adanya ketidakcocokan antara teori dan praktek menyebabkan reaksi terhadap pengumuman stock split sangat sulit untuk dipahami. Beberapa bukti empiris menunjukkan bahwa pasar memberikan reaksi positif terhadap pengumuman stock split. Hal ini ditunjukkan oleh hasil penelitian yang pernah dilakukan oleh Kadiyala dan Vetsuypens (2002) pada perusahaan-perusahaan yang melakukan stock split di pasar modal New York. Hasil penelitian tersebut menunjukkan bahwa stock split mempengaruhi kinerja keuangan perusahaan khususnya profitabilitas perusahaan, yaitu mempengaruhi Return on Asset (ROA). Demikian pula dengan penelitian yang dilakukan oleh Asquith, Healy dan Palepu (1989) yang menunjukkan adanya peningkatan laba (earnings) perusahaan yang melakukan stock split.

Dalam stock split terdapat dua hipotesis utama mengapa perusahaan melakukan tindakan tersebut. Hipotesis tersebut adalah Signaling Hypothesis dan Trade Range Hypothesis (Muazaroh dan Rr. Imrani, 2006). Hipotesis pertama yaitu Signaling Hypothesis, merupakan tindakan manajemen perusahaan untuk memberikan informasi mengenai pendapatan masa yang akan datang. Hipotesis ini juga menyatakan bahwa stock split memberikan informasi kepada investor tentang prospek peningkatan return masa depan yang substantial. Pemecahan saham yang dilakukan oleh perusahaan akan diinterpretasikan oleh investor sebagai sinyal positif bahwa manajer memiliki prospek yang baik di mana hal tersebut ditunjukkan dengan adanya abnormal return yang positif di sekitar pengumuman split (Jogiyanto, 2010: 564). Abnormal Return merupakan selisih dari actual return (return yang sesungguhnya terjadi) terhadap expected return (return yang diharapkan), yang dapat dirumuskan sebagai berikut: $R T N_{i, t}=R_{i, t}-$ $E\left[R_{i, t}\right]$. Di mana Rit merupakan actual return, yang dapat dihitung menggunakan closing price harian dengan formula sebagai berikut: $R i_{j} t=\frac{P_{i} t-P_{i} t-1}{P_{i} t-1}$. Sedangkan expected return dapat diestimasi menggunakan 3 model, yaitu: 
1. Mean adjusted model yaitu model yang menganggap bahwa return ekspektasian bernilai konstan yang sama dengan ratarata return realisasian sebelumnya pada periode estimasi

2. Market model yaitu model ekpektasi yang dapat dibentuk dengan menggunakan teknik regresi OLS (Ordinary Least Square)

3. Market adjusted model yaitu model yang menganggap penduga yang terbaik untuk mengestimasi return suatu sekuritas adalah return indeks pasar pada saat tersebut (Jogiyanto, 2010).

Penelitian yang mendukung hipotesis ini adalah penelitian yang dilakukan oleh Ikenbery et al (1996) dan Desai dan Jain (1997) yang menemukan abnormal return pada 3 tahun setelah pengumuman split. Dalam konteks pasar modal Indonesia sendiri, terdapat penelitian yang tidak mendukung hipotesis ini. Penelitian tersebut dilakukan oleh Wang Sutrisno et al (2000) dimana hasil dari penelitian ini menunjukkan bahwa stock split hanya mempengaruhi harga, volume perdagangan, dan persentase spread, tetapi tidak mempengaruhi varians dan abnormal return baik ditinjau secara individual maupun sebagai sebuah portofolio.

Hipotesis yang kedua yaitu Trade Range Hypothesis. Dalam hipotesis ini dinyatakan bahwa stock split akan meningkatkan likuiditas perusahaan. Harga saham yang terlalu tinggi, akan menyebabkan permintaan terhadap pembelian saham tersebut menurun dan pada akhirnya dapat menyebabkan harga saham perusahaan tersebut menjadi tidak fluktuatif lagi. Penurunan permintaan tersebut dapat disebabkan karena tidak semua investor tertarik untuk membeli saham dengan harga yang terlalu tinggi, terutama investor perorangan yang memiliki tingkat dana terbatas, yang terjadi kemudian adalah para investor akan berbalik untuk membeli saham-saham perusahaan lain.

Menurut Variyetmi Wira (2001) likuiditas saham dapat diukur menggunakan beberapa proksi. Pertama, bid-ask Spread saham, yaitu selisih dari harga ask dengan harga Bid dibandingkan dengan harga Ask. Kedua, Trading Turnover atau lebih dikenal dengan TVA yaitu total volume perdagangan yang diukur dengan jumlah saham yang diperdagangkan dibandingkan dengan jumlah saham yang dikeluarkan oleh perusahaan.

Ketiga, Frekuensi Perdagangan, yaitu banyaknya transaksi yang terjadi di pasar modal. Dengan adanya stock split maka harga saham akan menjadi lebih rendah sehingga akan lebih mudah dijangkau oleh investor, hal ini akan meningkatkan permintaan saham dan saham menjadi lebih likuid. Akan tetapi, Copeland dalam Jogiyanto (2010) menemukan hal yang sebaliknya dengan hipotesis ini, yaitu likuiditas pasar akan semakin rendah setelah stock split, yaitu volume perdagangan menjadi lebih rendah dibandingkan sebelumnya, biaya transaksi pialang secara proporsi meningkat dan bid - ask - spread (selisih harga bid yang diajukan oleh pembeli dan harga ask yang diminta oleh penjual) juga lebih tinggi dari sebelumnya.

Berdasarkan uraian di atas penelitian ini bertujuan untuk mengetahui: (1) perbedaan abnormal return saham dan likuiditas saham sebelum dan sesudah peristiwa stock split. 
Dalam hal ini, peneliti ingin mengamati abnormal return dan likuiditas saham di mana pengumuman stock split dijadikan sebagai event. Likuiditas perusahaan akan diukur dengan proksi volume perdagangan saham atau Trading Volume Activity (TVA). Volume perdagangan saham merupakan jumlah satuan unit saham yang diperjualbelikan dalam satuan periode tertentu, dimana dalam penelitian ini yang digunakan adalah periode harian.

Penelitian diharapkan dapat memberikan tiga manfaat. Manfaat pertama dapat memberikan informasi kepada investor sebagai acuan dalam menyikapi tindakan perusahaan yang melakukan stock split sehingga investor mampu melakukan pengambilan keputusan yang tepat. Manfaat kedua dapat memberikan informasi mengenai dampak/pengaruh dari keputusan melakukan split terutama terhadap likuiditas sehingga akan lebih berhati-hati dalam mempertimbangkan kebijakan perusahaan yang akan diambil terutama kebijakan mengenai stock split. Manfaat ketiga dapat memberikan tambahan literatur mengenai praktek stock split dan pertimbangan pada penelitian yang akan datang tentang pasar modal khususnya yang terkait dengan stock split.

\section{METODE}

Penelitian ini menggunakan desain event study yaitu penelitian yang mempelajari reaksi pasar terhadap suatu peristiwa (event) yang informasinya dipublikasikan sebagai suatu pengumuman (Jogiyanto, 2010: 561). Penelitian ini dilakukan selama 20 hari perdagangan terdiri dari 10 hari sebelum dan 10 hari sesudah stock split. Populasi dari penelitian ini adalah perusahaanperusahaan yang listing di Bursa Efek Indonesia dan mengeluarkan kebijakan stock split. Penentuan sampel dilakukan secara purposive sampling di mana sampel dipilih dengan kriteria perusahaan yang melakukan stock split tahun 2008-2012 dan Saham biasa yang aktif diperdagangkan.

Sampel yang diambil adalah perusahaanyang hanya melakukan peristiwa stock split dan tidak melakukan kebijakan lain selama periode peristiwa. Berdasarkan kriteria tersebut, diperoleh sampel sebanyak 31 perusahaan. Data yang digunakan adalah data sekunder berupa data harga saham penutupan harian, indeks harga saham gabungan harian, jumlah saham yang diperdagangkan harian dan jumlah saham yang beredar harian selama periode peristiwa dari tahun 2008-2012. Sumber data yang digunakan dalam penelitian ini adalah data yang dipublikasikan Divisi Riset dan Pengembangan BEI yang berupa Indonesian Capital Market Directory (ICMD) tahun 20082012, idx.co.id dan yahoofinance.

Dalam penelitian ini, variabel likuiditas diukur menggunakan proksi volume perdagangan saham. Abnormal return merupakan selisih antara actual return dan expected return. Expected return akan diestimasi menggunakan market model yang dapat dinyatakan sebagai berikut: $\mathrm{Ri}=\alpha+$ $\beta R m$, di mana Ri adalah return individu dan $\mathrm{Rm}$ adalah market return. Analisis data dalam penelitian ini menggunakan Uji Paired Sample t-test dan Uji Wilcoxon Signed Rank test. 


\section{HASIL DAN PEMBAHASAN}

Berikut ini akan diuraikan hasil pengujian hipotesis-hipotesis yang diajukan dalam penelitian ini. Hipotesis pertama dalam penelitian ini adalah adanya pendugaan perbedaan yang signifikan antara abnormal return sebelum dan sesudah stock split. Hasil analisis dari uji Paired t-test

Tabel 1. Ringkasan Uji Hipotesis I

\begin{tabular}{cc}
\hline Data & Abnormal Return \\
\hline t-hitung & 0,891 \\
Sig (2-tailed) & 0,380 \\
\hline
\end{tabular}

Berdasarkan Tabel 1 di atas dapat dilihat harga t hitung sebesar 0,891 dengan taraf signifikansi 0,380. Dengan demikian $\mathrm{P}>0,05$ maka Ho diterima dan $\mathrm{Ha}$ ditolak. Kesimpulannya bahwa tidak terdapat perbedaan yang signifikan antara rata-rata abnormal return sebelum dan sesudah stock split. Hasil penelitian ini berlawanan dengan signaling theory karena investor dapat memprediksi informasi yang dibawa oleh adanya peristiwa stock split dan lebih mempercayai perusahaan yang benar-benar memberikan return dari pada perusahaan yang hanya menjanjikan keuntungan di masa yang akan datang.

Abnormal return pada hari-hari sesudah stock split cenderung bernilai negatif, hal ini berarti pasar kurang bergairah karena investor sepertinya enggan untuk berinvestasi dengan harga saham ada. Para investor masih berhati-hati dengan nilai abnormal return yang cenderung negatif. Mereka lebih memilih untuk menunggu abnormal return beranjak ke nilai positif terlebih dahulu supaya investasinya mendapatkan return yang seoptimal mungkin. Hal ini juga menunjukkan bahwa pasar tidak bereaksi secara positif atas peristiwa stock split. Hasil penelitian ini mendukung penelitian yang dilakukan oleh Wang Sutrisno (2000) yang menyatakan bahwa stock split tidak mempengaruhi abnormal return baik ditinjau secara individual maupun sebagai sebuah portofolio. Penelitian lain yang mendukung hasil penelitian ini dilakukan oleh Ana Wayifah (2005) yang menyatakan bahwa tidak terdapat perbedaan abnormal return yang signifikan pada pengumuman stock split.

Dengan demikian secara keseluruhan uji hipotesis pertama, menunjukkan tidak terdapat perbedaan antara abnormal return saham sebelum dan sesudah stock split. Selain itu, pengumuman stock split tidak mempengaruhi investor dalam melakukan transaksi di pasar modal yang dilihat dari tingkat keuntungan/rata-rata abnormal return saham sebelum dan sesudah pengumuman.

Hipotesis kedua dalam penelitian ini adalah pendugaan adanya perbedaan yang signifikan antara likuiditas saham sebelum dan sesudah stock split. Hasil analisis dari uji Paired t-test.

Tabel 2. Ringkasan Uji Hipotesis II

\begin{tabular}{cccc}
\hline TVA & A & Z & $\begin{array}{c}\text { Asymp.Sig } \\
\text { (2-tailed) }\end{array}$ \\
\hline $\begin{array}{c}\text { Sebelum- } \\
\text { sesudah }\end{array}$ & 0,05 & $-4,157$ & 0,000 \\
\hline
\end{tabular}

Tabel 2 menyajikan hasil uji Wilcoxon Signed Rank mengenai likuiditas saham yang diukur menggunakan volume perdagangan saham sebelum dan sesudah peristiwa stock split. Diperoleh nilai $Z_{\text {hitung }}$ yang dihasilkan sebesar|-4,157|lebih besar dari pada nilai 
$Z_{\text {tabel }}$ yaitu sebesar 1,96 dengan tingkat signifikansi yang dihasilkan sebesar 0,000 dimana nilai ini lebih kecil dari tingkat signifikansi yang disyaratkan yaitu sebesar 0,05 . Oleh karena nilai $Z_{\text {hitung }}|-4,860|>Z_{\text {tabel }}$ 1,96 dan tingkat signifikansi yang dihasilkan lebih kecil dari 0,05 maka $\mathrm{H}_{0}$ ditolak dan $\mathrm{H}_{\mathrm{a}}$ diterima. Dengan demikian dapat disimpulkan bahwa terdapat perbedaan yang signifikan antara likuiditas saham sebelum dan sesudah peristiwa stock split. Hal ini juga membuktikan bahwa stock split mampu meningkatkan likuiditas saham.

\section{SIMPULAN}

Pengujian hipotesis pertama menggunakan Uji Paired t-test, ditemukan bahwa tidak terdapat perbedaan yang signifikan antara abnormal return sebelum dan sesudah stock split, sehingga dapat dikatakan bahwa stock split tidak meningkatkan abnormal return saham. Abnormal return yang diperoleh sebagian besar bernilai negatif yang berarti bahwa kandungan informasi dalam peristiwa tersebut merupakan berita buruk (bad news).

Pengujian hipotesis kedua menggunakan Uji Wilcoxon Signed Rank Test, ditemukan bahwa terdapat perbedaan signifikan antara likuiditas saham sebelum dan sesudah stock split. Rata-rata volume perdagangan saham yang dihasilkan sesudah stock split menunjukkan adanya peningkatan jika dibandingkan dengan rata-rata volume perdagangan saham sebelum stock split. Hal ini menunjukkan bahwa stock split membuat harga saham menjadi lebih terjangkau sehingga mampu menjadikan saham menjadi lebih likuid.

\section{DAFTAR PUSTAKA}

Ana Wayifah. (2005) Reaksi Pasar Pada Pengumuman Stock Split dan Reserve Split (Study Pada Perusahaan yang Terdaftar di BEJ).

Desai, Hemang, Prem C. Jain. (1997) LongRun Common Stock Returns Following Stock Splits and Reverse Splits. Journal of Business, 70(3), 409-433.

Indonesian Capital Market Directory 20022012

Jogiyanto Hartono. (2010) Teori Portofolio dan Analisis Investasi. Yogyakarta: BPFE.

Kadiyala \& Vetsuypens. (2002) Are Stock Splits Credible Signals? Evidence from Short-Interest Data. Financial Management, 31(1), 31-49.

Mohamad Samsul. (2006) Pasar Modal dan Manajemen Portofolio. Jakarta: Erlangga.

Muazaroh \& Rr. Iramani. (2006) Analisis Kinerja Keuangan, Kemahalan Saham dan Likuitas Pada Pemecahan Saham. Jurnal Ventura, 9(1), 45-60.

Variyetmi Wira. (2012) Pengaruh Kinerja Perusahaan terhadap Likuiditas Saham Menggunakan Trading Turnover (Studi Kasus Perusahaan yang Terdaftar di Bursa Efek Indonesia). Jurnal Manajemen dan Kewirausahaan, 3(2), 97-120.

Wang Sutrisno, Fransisca Yuniartha, Soffy Susilowati. (2000) Pengaruh Stock Split Terhadap Likuiditas dan Return Saham di Bursa Efek Jakarta. Jurnal Manajemen \& Kewirausahaan. 2(2), 1-13. 